\title{
Body composition, resting energy expenditure and inflammatory markers: impact in users of depot medroxyprogesterone acetate after 12 months follow-up
}

\begin{abstract}
Gisele Almeida Batista', Aglécio Luiz de Souza', Daniela Miguel Marin', Marina Sider ${ }^{1}$, Vaneska Carvalho Melhado', Arlete Maria Fernandes', Sarah Monte Alegre'
\end{abstract}

${ }^{1}$ Faculdade de Ciências Médicas, Universidade Estadual de Campinas (FCM-Unicamp) Campinas, SP, Brasil

Correspondence to: Sarah Monte Alegre Rua Tessália Viera de Camargo, 126 Cidade Universitária Zeferino Vaz 13083-887 - Campinas, SP, Brasil salegre@fcm.unicamp.br

Received on Oct/6/2015 Accepted on Mar/7/2016

DOI: 10.1590/2359-3997000000202

\begin{abstract}
Objective: The aim of this study was to evaluate for 12 months the changes of body weight using Depot Medroxyprogesterone Acetate (DMPA) and if these changes are related to inflammatory markers. Subjects and methods: Twenty women of childbearing age who chose the DMPA, without previous use of this method, $\mathrm{BMI}<30 \mathrm{~kg} / \mathrm{m}^{2}$, and 17 women using IUDTCu $380 \mathrm{~A}$, participated in the study. At the baseline and after one year, changes in weight gain, body composition by the bioimpedance electric method, resting energy expenditure (REE) by the indirect calorimetry method, inflammatory markers and HOMA-IR were assessed. Results: After 12 months of evaluation, we could observe a significant increase in the DMPA group in weight $(3,01 \mathrm{~kg})$ and BMI, while the IUD group's only significant increase was observed in the BMI. Relative to REE there was an increase of basal metabolic rate (BMR) in both groups after one year. The sub-group DMPA that gained $<3 \mathrm{~kg}$ had increased significant weight, $\mathrm{BMI}$ and body surface (BS) with respiratory quotient (RQ) reduction, while the sub-group that gained $\geq 3 \mathrm{~kg}$ had a significant increase in weight, BMI, BS, fat-free mass, fat mass, BMR, Leptin, HOMA-IR and waist circumference, with RO significantly reduced. Conclusion: Our study found significant changes in weight, body composition and metabolic profile of the population studied in the first 12 months of contraceptive use. These changes mainly increased body weight, leptin levels and HOMA-IR which can contribute to the development of some chronic complications, including obesity, insulin resistance and diabetes mellitus. Arch Endocrinol Metab. 2017;61(1):70-5
\end{abstract}

Keywords

Obesity; body composition; resting energy expenditure; depot medroxyprogesterone acetate; leptin

\section{INTRODUCTION}

$\mathrm{O}$ besity is considered a serious public health problem that affects developed countries as well as developing ones. Globally, there are an estimated 1.5 billion overweight adults, of which approximately 500 million are obese (1). In Brazil, 50.8\% of the population over 18 years old are overweight and $17.5 \%$ are obese (2). This complex and chronic disorder of multifactorial etiology is the result of positive energy balance, and genetic and environmental factors are involved in developing this metabolic disorder $(3,4)$. In women, the use of hormonal contraceptives has been associated with weight gain and changes in body composition.

Depot medroxyprogesterone acetate (DMPA) is an injectable contraceptive method and in its formulation contains $150 \mathrm{mg}$ of DMPA administered every 3 months intramuscularly at a plasma concentration of approximately $\mathrm{l} \mathrm{ng} / \mathrm{mL}$ (5). According to the characteristics of contraceptive efficacy, safety and low cost, and ease of access due to its ready availability from public health systems in several countries, including Brazil, millions of women choose to use this method (6). Despite having a potential negative effect on bones, the most common reason for discontinuing use of DMPA is increased body weight (7). Most prospective studies that have assessed the body composition of these progestin users, with at least 30 months of use, show a weight gain associated with an increase in body fat deposits $(8,9)$.

In a study with HIV-infected women was evaluated the association between DMPA use with inflammatory markers (10). However, no studies in healthy women linking weight gain after using DMPA with 
inflammatory markers. Therefore, the aim of this study was to evaluate for 12 months the changes of body weight using DMPA and if these changes are related to inflammatory markers.

\section{SUBJECTS AND METHODS}

\section{Subjects}

This was a prospective cohort study with women attending the family planning clinic at the Gynecology and Obstetrics Department, University of Campinas (Unicamp), Brazil. Sample size was calculated from the demand for women seen in the clinic who opted for the contraceptive DMPA method and the percentage of women who have segment to method use for at least 12 months. The women were selected from February 2011 to March 2012.

Women of childbearing age who chose the injectable contraceptive DMPA without previous use of this method, body mass index $(\mathrm{BMI})<30 \mathrm{~kg} / \mathrm{m}^{2}$, and women using the non-hormonal contraception copper intrauterine device (TCu 380A IUD), were invited to participate in the study. The participants were aged between 18 and 40 years. The groups were paired at baseline, becoming a homogeneous group in relation to age $( \pm 1$ year $)$, and BMI $\left( \pm 1 \mathrm{~kg} / \mathrm{m}^{2}\right)$.

After signing an informed consent form, they were interviewed to collect data and personal medical and family history. An administration every three months of $150 \mathrm{mg}$ of DMPA was given and follow-up was maintained for one year. The women in the control group, TCu 380A IUD users, underwent the same procedures provided for inclusion into the DMPA group.

Exclusion criteria were: women with diabetes mellitus (DM) type 1 or 2 ; those with a family history of diabetes; those who had fasting glucose $>100 \mathrm{mg} / \mathrm{dL}$ after 8 hours of fasting or after a 120 minute oral glucose tolerance test had 75 g glucose blood glucose $>140 \mathrm{mg} / \mathrm{dL}$; women breast-feeding; those with comorbidities that contribute to the variation in body weight such as hyper- and hypothyroidism; chronic renal failure and transplant of any organ; use of medications that may be related to weight gain and/or development of insulin resistance such as the chronic use of corticosteroids, antipsychotics, diuretics and statins. Patients with hirsutism and/or hyperandrogenism and polycystic ovary syndrome were also excluded.

Initially, 49 women were evaluated. Throughout the monitoring period, 11 volunteers were excluded either for not returning for follow-up or because they became pregnant. One participant was excluded from the group by initiating physical activity after use of DMPA. At the end of the study we evaluated 37 women, 20 from the DMPA group and 17 from the IUD group (Figure 1).

This study was approved by the Ethics Committee of the Faculty of Medical Sciences - Unicamp, and all the volunteers who agreed to participate signed a consent form.

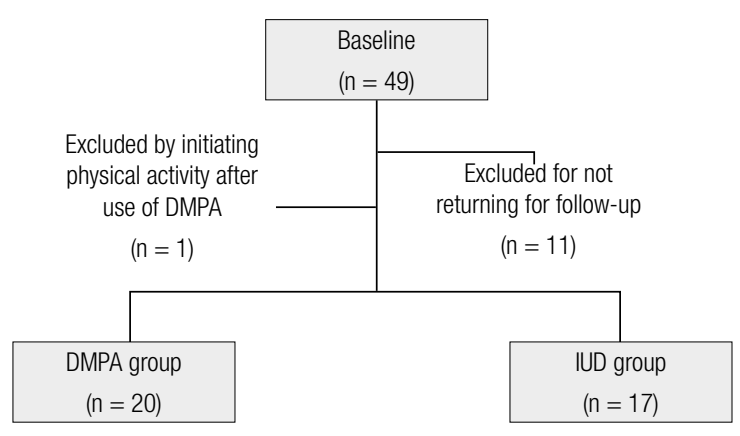

Figure 1. Flow chart of the study.

\section{Anthropometric measurements and body composition}

Anthropometric assessment was performed by a single examiner. Weight $(\mathrm{kg})$ and height $(\mathrm{m})$ were measured using a Welmy mechanical scale with $100 \mathrm{~g}$ precision and capacity of $200 \mathrm{~kg}$. Height was measured by a stadiometer coupled to the scale with a precision of $0.5 \mathrm{~cm}$. Waist circumference (WC) was measured with an inelastic $2 \mathrm{~m}$ tape dimension. The anatomical point used was the midpoint between the last rib and the iliac crest.

Nutritional status was assessed by calculating the BMI, recommended by the World Health Organization 1995 and 1997 (11).

The percent body fat (\% fat), weight, fat mass (FM) and fat-free mass (FFM) were assessed by Bioimpedance Electric (BIA) using the equipment Biodynamics Bioimpedance Analiser model 310.

\section{Resting energy expenditure}

The resting energy expenditure (REE), basal metabolic rate (BMR) and substrate used to obtain energy were assessed by the indirect calorimetry method. For this, a Vmax Encore 29 device coupled to a canopy gas exchange was used. 
The consumption of oxygen $\left(\mathrm{O}_{2}\right)$ and the elimination of carbon dioxide $\left(\mathrm{CO}_{2}\right)$ in liters per minute as well as tidal volume were reported in this procedure. From these primary measures, the values of energy expenditure in kilocalories per day were obtained along with the respiratory quotient (RQ). The mean values obtained in steady state, prefixed as smaller variations than $5 \%$ in RQ and $10 \%$ in $\mathrm{CO}_{2}$ were considered.

\section{Biochemical assays}

Serum adiponectin, interleukin (IL) - 6, visfatin, leptin, tumor necrosis factor- $\alpha$ (TNF- $\alpha)$, insulin and glucose were performed at baseline and after one year of using the method. The blood samples were centrifuged, and serum was immediately stored in small aliquots in a freezer at $-80^{\circ} \mathrm{C}$. Dosages of adipocytokines and insulin were performed in serum by enzyme immunoassay in duplicate by enzyme-linked immunosorbent assay (ELISA) using commercial kits with high sensitivity and specificity.

\section{Insulin resistance}

Homeostasis model assessment of insulin resistance (HOMA-IR) was calculated according to the formula: fasting insulin $(\mu \mathrm{U} / \mathrm{L}) \mathrm{x}$ fasting glucose $(\mathrm{nmol} / \mathrm{L}) / 22.5$. Those considered normal values are $<2.7$ (12).

\section{Statistical analysis}

All results are expressed as mean $\pm \mathrm{SD}$. The MannWhitney test was used to compare the variables between two groups. The Wilcoxon test was used for comparison of group time fixing. For comparison of numerical measurements between times and groups ANOVA was used for repeated measurements with transformation stations. The significance level for statistical tests was $5 \%(\mathrm{P}<0.05)$. The SAS program for Windows version 9.2 was used to perform the analyses.

\section{RESULTS}

After 12 months of evaluation, we could observe a significant increase in the DMPA group in weight $(61.95 \mathrm{~kg} \pm 9.69 \times 64.96 \mathrm{~kg} \pm 9.40, \mathrm{p}=0.0007)$, BMI $\left(23.74 \mathrm{~kg} / \mathrm{m}^{2} \pm 3.47 \times 24.88 \mathrm{~kg} / \mathrm{m}^{2} \pm 3.43\right.$, $\mathrm{p}=0.0007)$ and body surface (BS) $(1.65 \pm 0.14 \mathrm{x}$ $1.69 \pm 0.13 \mathrm{p}=0.0148)$, while the IUD group's only significant increase was observed in the BMI variable $\left(24.26 \mathrm{~kg} / \mathrm{m}^{2} \pm 2.67 \times 24.56 \mathrm{~kg} / \mathrm{m}^{2} \pm 2.84, \mathrm{p}=\right.$ 0.0007 ) (Table 1 ).

Relative to REE and RQ, there was an increase of BMR in both groups after one year (DMPA group: $1087.05 \mathrm{kcal} / \mathrm{d} \pm 252.06 \times 1319.30 \mathrm{kcal} / \mathrm{d} \pm 133.53$, $\mathrm{p}=0.0027$, IUD group: $1187.59 \mathrm{kcal} / \mathrm{d} \pm 246.23 \mathrm{x}$ $1303.18 \mathrm{kcal} / \mathrm{d} \pm 104.02, \mathrm{p}=0.0027)$. The RQ was significantly reduced after 12 months of study in groups DMPA $(0.91 \times 0.77, \mathrm{p}<0.0001)$ and IUD $(0.87 \times$ $0.78, \mathrm{p}<0.0001)$ (Table 2).

Table 3 shows the subdivision of the DMPA group for weight gain after 12 months follow-up. The sub-group that gained $<3 \mathrm{~kg}$ had a significant increase in weight $(61.24 \mathrm{~kg} \pm 10.38 \times 62.51 \mathrm{~kg} \pm 9.95, \mathrm{p}=0.0156), \mathrm{BMI}$ $\left(23.44 \mathrm{~kg} / \mathrm{m}^{2} \pm 4.25 \times 23.93 \mathrm{~kg} / \mathrm{m}^{2} \pm 4.15, \mathrm{p}=0.0313\right)$ and BS $(1.64 \pm 0.12 \times 1.66 \pm 0.12 \mathrm{p}=0.0313)$ with $\mathrm{RQ}$ reduction $(0.87 \pm 0.09 \times 0.77 \pm 0.03, \mathrm{p}=0.0313)$, while the sub-group that gained $\geq 3 \mathrm{~kg}$ had a significant increase in weight $(61.1 \mathrm{~kg} \pm 8.63 \times 66.63 \mathrm{~kg} \pm 8.48$, $\mathrm{p}=0.002)$, BMI $\left(23.47 \mathrm{~kg} / \mathrm{m}^{2} \pm 3.50 \times 25.55 \mathrm{~kg} /\right.$ $\left.\mathrm{m}^{2} \pm 3.46, \mathrm{p}=0.002\right)$, BS $(1.64 \pm 0.11 \times 1.71 \pm 0.11$, $\mathrm{p}=0.002)$, FFM $(42.01 \mathrm{~kg} \pm 4.18 \times 45.19 \mathrm{~kg} \pm 4.74$, $\mathrm{p}=0.0059), \mathrm{FM}(19.14 \mathrm{~kg} \pm 5.26 \times 21.44 \mathrm{~kg} \pm 5.82$, $\mathrm{p}=0.0273), \mathrm{BMR}(997.70 \mathrm{kcal} / \mathrm{d} \pm 202.72 \times 1318.20$ $\mathrm{kcal} / \mathrm{d} \pm 157.58, \mathrm{p}=0.0117)$, Leptin $(78.05 \pm 76.25 \mathrm{x}$ $236.86 \pm 214.93, \mathrm{p}=0.0195), \mathrm{HOMA}-\mathrm{IR}(0.70 \pm 0.41$ $\mathrm{x} 1.92 \pm 1.41, \mathrm{p}=0.0059)$ and $\mathrm{WC}(75.90 \mathrm{~cm} \pm 7.52$ $\mathrm{x} 79.49 \mathrm{~cm} \pm 7.75, \mathrm{p}=0.002)$, with RQ significantly reduced $(0.95 \pm 0.12 \times 0.77 \pm 0.04, \mathrm{p}=0.002)$.

Table 1. Characteristics of the DMPA and DIU groups

\begin{tabular}{|c|c|c|c|c|c|c|}
\hline \multirow[b]{2}{*}{ Variable } & \multicolumn{2}{|c|}{ Baseline } & \multirow[b]{2}{*}{$¥ P$ value } & \multicolumn{2}{|c|}{12 months } & \multirow[b]{2}{*}{$¥ P$ value } \\
\hline & $\begin{array}{c}\text { DMPA } \\
(n=20)) \\
\text { Mean } \pm \text { SD }\end{array}$ & $\begin{array}{c}\text { IUD } \\
(n=17) \\
\text { Mean } \pm \text { SD }\end{array}$ & & $\begin{array}{c}\text { DMPA } \\
(n=20) \\
\text { Mean } \pm \text { SD }\end{array}$ & $\begin{array}{c}\text { IUD } \\
(n=17) \\
\text { Mean } \pm \text { SD }\end{array}$ & \\
\hline Age (years) & $29,7 \pm 6,2$ & $28,4 \pm 5,8$ & 0,4682 & - & - & \\
\hline Weight (kg) & $61,95 \pm 9,69$ & $61,24 \pm 6,98$ & 0,5449 & $64,96^{\star} \pm 9,40$ & $61,76 \pm 7,53$ & 0,0007 \\
\hline BMI $\left(\mathrm{kg} / \mathrm{m}^{2}\right)$ & $23,74 \pm 3,47$ & $24,26 \pm 2,67$ & 0,911 & $24,88^{\star} \pm 3,43$ & $24,56^{\star \star} \pm 2,84$ & 0,0007 \\
\hline BS & $1,65 \pm 0,14$ & $1,62 \pm 0,09$ & 0,4127 & $1,69^{*} \pm 0,13$ & $1,63 \pm 0,10$ & 0,0148 \\
\hline WC (cm) & $75,47 \pm 7,28$ & $77,61 \pm 7,88$ & 0,0178 & $76,74 \pm 6,27$ & $75,38 \pm 5,66$ & 0,1834 \\
\hline
\end{tabular}

$¥:$ Mann-Whitney test. Statistical significance: $p<0,05$. ${ }^{*}$ Depo group difference between baseline and after 12 months. ${ }^{\star}$ DIU group difference between baseline and after 12 months. BS: body surface; WC: waist circumference; BMl: body mass index. 
Table 2. Resting energy expenditure and respiratory quotient baseline and after 12 months

\begin{tabular}{|c|c|c|c|c|c|c|}
\hline \multirow[b]{2}{*}{ Variable } & \multicolumn{2}{|c|}{ Baseline } & \multirow[b]{2}{*}{$¥ P$ value } & \multicolumn{2}{|c|}{12 months } & \multirow[b]{2}{*}{$¥ P$ value } \\
\hline & $\begin{array}{c}\text { DMPA } \\
(n=20) \\
\text { Mean } \pm \text { SD }\end{array}$ & $\begin{array}{c}\text { IUD } \\
(n=17) \\
\text { Mean } \pm \text { SD }\end{array}$ & & $\begin{array}{c}\text { DMPA } \\
(n=20) \\
\text { Mean } \pm \text { SD }\end{array}$ & $\begin{array}{c}\text { IUD } \\
(n=17) \\
\text { Mean } \pm \text { SD }\end{array}$ & \\
\hline BMR (kcal/d) & $1087,05 \pm 252,06$ & $1187,59 \pm 246,23$ & 0,3674 & $1319,30^{*} \pm 133,53$ & $1303,18^{\star \star} \pm 104,02$ & 0,0027 \\
\hline $\mathrm{RQ}$ & $0,91 \pm 0,11$ & $0,87 \pm 0,09$ & 0,8134 & $0,77^{\star} \pm 0,03$ & $0,78^{\star \star} \pm 0,03$ & $<0,0001$ \\
\hline
\end{tabular}

$¥:$ Mann-Whitney test. Statistical significance: $p<0,05$. ${ }^{*}$ Difference Depo group between baseline and after 12 months. ${ }^{\star \star}$ Difference IUD group between baseline and after 12 months. $\mathrm{RQ}$ : respiratory quotient; BMR: basal metabolic rate.

Table 3. Characteristics of DMPA group subdivided by weight gain after12 months

\begin{tabular}{|c|c|c|c|c|c|c|}
\hline & Baseline & 12 months & \multirow{3}{*}{$+P$ value } & Baseline & 12 months & \multirow{3}{*}{$+P$ value } \\
\hline & \multicolumn{2}{|c|}{$<3 \mathrm{~kg}(\mathrm{n}=7)$} & & \multicolumn{2}{|c|}{$>3 \mathrm{~kg}(\mathrm{n}=10)$} & \\
\hline & Mean \pm SD & Mean \pm SD & & Mean \pm SD & Mean \pm SD & \\
\hline Weight & $61,24 \pm 10,38$ & $62,51^{c} \pm 9,95$ & 0,0156 & $61,1 \pm 8,63$ & $66,63^{\mathrm{d}} \pm 8,48$ & 0,002 \\
\hline BMl & $23,44 \pm 4,25$ & $23,93^{c} \pm 4,15$ & 0,0313 & $23,47 \pm 3,50$ & $25,55^{d} \pm 3,46$ & 0,002 \\
\hline BS & $1,64 \pm 0,12$ & $1,66^{c} \pm 0,12$ & 0,0313 & $1,64 \pm 0,11$ & $1,71^{\mathrm{d}} \pm 0,11$ & 0,002 \\
\hline$\%$ Fat & $30,70 \pm 5,58$ & $29,30 \pm 6,99$ & 0,5625 & $30,87 \pm 4,58$ & $31,76 \pm 6,12$ & 0,7891 \\
\hline FFM & $42,51 \pm 5,32$ & $43,94 \pm 6,50$ & 0,1406 & $42,01 \pm 4,18$ & $45,19^{d} \pm 4,74$ & 0,0059 \\
\hline $\mathrm{FM}$ & $19,44 \pm 6,07$ & $18,57 \pm 6,20$ & 0,7813 & $19,14 \pm 5,26$ & $21,44^{d} \pm 5,82$ & 0,0273 \\
\hline BMR & $1224,43 \pm 266,82$ & $1334,29 \pm 125,04$ & 0,1563 & $997,70 \pm 202,72$ & $1318,20^{d} \pm 157,58$ & 0,0117 \\
\hline $\mathrm{RQ}$ & $0,87 \pm 0,09$ & $0,77^{\mathrm{c}} \pm 0,03$ & 0,0313 & $0,95 \pm 0,12$ & $0,77^{\mathrm{d}} \pm 0,04$ & 0,002 \\
\hline Adiponectin & $10,20 \pm 3,21$ & $8,60 \pm 4,82$ & 0,375 & $5,89 \pm 1,90$ & $5,96 \pm 2,80$ & 0,8457 \\
\hline Leptin & $133,53 \pm 156,77$ & $174,20 \pm 184,10$ & 0,2969 & $78,05 \pm 76,25$ & $236,86^{d} \pm 214,93$ & 0,0195 \\
\hline Visfatin & $44,78 \pm 10,82$ & $45,76 \pm 21,36$ & 0,8125 & $50,68 \pm 31,83$ & $43,81 \pm 16,23$ & 0,4316 \\
\hline IL-6 & $1,30 \pm 0,42$ & $1,91 \pm 1,80$ & 1 & $1,12 \pm 0,77$ & $2,02 \pm 2,71$ & 1 \\
\hline TNF- $\alpha$ & $4,70 \pm 2,11$ & $4,28 \pm 3,33$ & 0,2969 & $4,31 \pm 1,98$ & $3,62 \pm 1,67$ & 0,1934 \\
\hline HOMA-IR & $1,25 \pm 1,44$ & $1,15 \pm 0,84$ & 0,5781 & $0,70 \pm 0,41$ & $1,92^{\mathrm{d}} \pm 1,41$ & 0,0059 \\
\hline WC & $74,14 \pm 8,35$ & $75,67 \pm 8,97$ & 0,125 & $75,90 \pm 7,52$ & $79,49^{d} \pm 7,75$ & 0,002 \\
\hline
\end{tabular}

+: Wilcoxon test. Statistical significance: $p<0,05$. c: Difference sub-group weight gain $<3 \mathrm{~kg}$ comparing baseline and after 12 months. d: Difference sub-group weight gain $>3 \mathrm{~kg}$ comparing baseline and after 12 months.

FFM: free fat mass; FM: fat mass; BMR: basal metabolic rate.

\section{DISCUSSION}

We can consider that our population has a differential in relation to other studies evaluating the effect of DMPA, considering that our group was paired with the control group at baseline for BMI $\left( \pm 1 \mathrm{~kg} / \mathrm{m}^{2}\right)$ and age $( \pm 1$ year), becoming a homogeneous group. Our study found that after 12 months of follow-up the injectable DMPA users had significant weight gain $(3.01 \mathrm{~kg})$. As most prospective studies evaluating the effect of DMPA were for at least 30 months $(6,8,9)$, we can consider that the follow-up period of our study is short compared to the others, but we can already observe significant changes in important variables studied.

To better assess changes in weight and body composition, we made a subdivision of the DMPA group for weight gain $(<3 \mathrm{~kg}$ and $>3 \mathrm{~kg})$, and observed significant changes in weight and body composition in both groups, but the group which gained $>3 \mathrm{~kg}$ had the more pronounced changes. This group had a mean gain of $5.53 \mathrm{~kg}$, increased fat mass $(2.3 \mathrm{~kg})$ and fat-free mass $(3.18 \mathrm{~kg})$ after 12 months follow-up. The increase in fat-free mass in users of DMPA may be explained by the androgenic effect of this contraceptive method (13).

Berenson and Rahman (9), to compare changes in weight and body composition between different contraceptive methods, observed at 24 months of follow-up an increase of $4.4 \mathrm{~kg}$ and after 36 months a gain of $5.1 \mathrm{~kg}$ in the DMPA group. Of the $5.1 \mathrm{~kg}$ that the volunteers put on after 36 months, $4.1 \mathrm{~kg}$ were of fat mass. Moreover, a significant increase in total body lean mass after 30 months of follow-up was observed. 
The main contributing factor to the increase in body weight after use of DMPA reported in most studies is the increase in fat deposits. After 30 months of follow-up of users of medroxyprogesterone, Clark and cols. (8) observed a gain of $6.1 \mathrm{~kg}$, which is fully represented by increased fat mass. There are two other possible mechanisms that might explain the weight gain associated with DMPA use: the first is its glucocorticoidlike activity, which appears to be associated with increased fat, including visceral fat (14). However, secondly, it is also possible that the state of hypoestrogenism induced by the injectable may be another factor responsible for the increase in weight and body fat (15).

In our study, the subgroup that gained more weight at the end of the study also had a significant increase in waist circumference and HOMA-IR. Increased waist circumference is indicative of an increase in subcutaneous and visceral adipose tissue. HOMA-IR, although not yet characterized as insulin resistance (HOMA-IR > 2.7) in our group, indicates a probable trend for the development of insulin resistance with increased exposure time for the contraceptive method. Accumulation of excess fat can be a critical modulation factor for insulin sensitivity, since it promotes the release of free fatty acids into the adipocyte circulation $(16,17)$. In addition, excess adiposity and adipocyte dysfunction result in dysregulation of adipokines, which may contribute to the development of various metabolic complications through altered glucose and lipid homeostasis as well as inflammatory responses $(18,19)$.

In relation to changes in inflammatory markers, we observed a slight decrease in adiponectin levels, although it was not significant in the DMPA group. A greater reduction in the levels of this marker associated with weight gain and increased body fat can contribute to the development of insulin resistance. Moreover, there was a significant increase in leptin levels in the group with greater weight gain. Leptin is directly related to body fat in both experimental models and in humans $(20,21)$, and is also related to food intake (22). These alterations relative to subclinical inflammation agree with those present in situations of obesity. The adipose tissue contributes to inflammation in both obese vascular and non-vascular tissues (23). Abnormal levels of fatty acids, lipids, cytokines and activate monocytes adipose tissue, increased secretion of inflammatory cytokines such as TNF- $\alpha$, leptin, interleukin (IL)-1, IL-6, visfatin and reduced the secretion of antiinflammatory cytokine adiponectin (24).
This study also has the important evaluation point of resting energy expenditure and respiratory quotient, given that data on basal metabolism with DMPA use are scarce, only two studies have assessed the resting energy expenditure in healthy women using DMPA $(25,26)$. The basal metabolic rate increased significantly in the DMPA group and control. However, a more significant increase in this variable in subgroup DMPA, which gained more weight $(>3 \mathrm{~kg}$ ), can be seen. This increase is mainly explained by an increase in fat mass and fat-free mass as well. In obese, the resting energy expenditure can be influenced mainly by fat-free mass, which is the largest contributing factor of variance of the basal metabolic rate (50-60\%), and fat mass which represents (5-6\%) of influence on the variation basal metabolic rate (27). The respiratory quotient of the two groups decreased after 12 months follow-up, indicating a change in metabolism of energy substrates. The volunteers at baseline had a characteristic respiratory quotient of high sugar metabolism but by the end of the study the profile changed with lipids starting to metabolize.

This study had the limitation of a small number of patients; including more patients could strengthen our results. Also we did not evaluate the lipid profile of the volunteers.

In conclusion, our study found significant changes in weight, body composition and metabolic profile of the population studied in the first 12 months of contraceptive use. These changes mainly increased body weight, leptin levels and HOMA-IR which can contribute to the development of some chronic complications, including obesity, insulin resistance and diabetes mellitus. According to the changes observed in our study, we suggest a more careful assessment of women who will start using the method as well as those who are already using this method of contraception. The exposure time method is considered the most important factor for the development of these changes.

Acknowledgements: we thank Fapesp for funding this research, Cleide Silva for their assistance in the analysis and statistical interpretation and to all the volunteers of this research.

Disclosure: no potential conflict of interest relevant to this article was reported.

\section{REFERENCES}

1. Finucane MM, Stevens GA, Cowan MJ, Danaei G, Lin JK, Paciorek CJ, et al.; Global Burden of Metabolic Risk Factors of 
Chronic Diseases Collaborating Group (Body Mass Index). National, regional, and global trends in body-mass index since 1980: systematic analysis of health examination surveys and epidemiological studies with 960 country-years and 9.1 million participants. Lancet. 2011;377(9765):557-67.

2. Ministério da Saúde, Secretaria de Vigilância em Saúde: Vigitel Brasil: vigilância de fatores de risco e proteção para doenças crônicas por inquérito telefônico. Brasília; 2012.

3. Aoi N, Soma M, NakayamaT, Rahmutula D, Kosuge K, Izumi Y, et al. Variable number of tandem repeat of the $5^{\prime}$-flanking region of type-C human natriuretic peptide receptor gene influences blood pressure levels in obesity-associated hypertension. Hypertens Res. 2004;27(10):711-6.

4. Kosuge K, Soma M, Nakayama T, Aoi N, Sato M, Haketa A, et al. Human uncoupling protein 2 and 3 genes are associated with obesity in Japanese. Endocrine. 2008;34(1-3):87-95.

5. Kahn HS, Curtis KM, Marchbanks PA. Effects of injectable or implantable progestin-only contraceptives on insulin-glucose metabolism and diabetes risk. Diabetes Care. 2003;26(1):216-25.

6. Pantoja M, Medeiros T, Baccarin MC, Morais SS, Bahamondes L, Fernandes AM. Variations in body mass index of users of depotmedroxyprogesterone acetate as a contraceptive. Contraception. 2010;81(2):107-11.

7. Bakry S, Abdullah A. Effect of depot medroxyprogesterone (DMPA) on body weight and serum lipid profile in adult female rats. Egypt J Biochem Molec Biol. 2008;2(1):17-30.

8. Clark MK, Dillon JS, Sowers M, Nichols S. Weight, fat mass, and central distribution of fat increase when women use depotmedroxyprogesterone acetate for contraception. Int $\mathrm{J}$ Obes (Lond). 2005;29(10):1252-8.

9. Berenson $A B$, Rahman $M$. Changes in weight, total fat, percent body fat, and central-to-peripheral fat ratio associated with injectable and oral contraceptive use. Am J Obstet Gynecol. 2009;200(3):329.e1-8.

10. Weinberg A, Park JG, Bosch R, Cho A, Livingston E, Aweeka F, et al. Effect of Depot Medoxyprogesterone Acetate on Immune Functions and Inflammatory Markers of HIV-Infected Women. J Acquir Immune Defic Syndr. 2016;71(2):137-45.

11. WHO. Obesity: preventing and managing the global epidemic. Genebra; 1997.

12. Geloneze B, Vasques AC, Stabe CF, Pareja JC, Rosado LE, Queiroz $E C$, et al. HOMA1-IR and HOMA2-IR indexes in identifying insulin resistance and metabolic syndrome: Brazilian Metabolic Syndrome Study (BRAMS). Arq Bras Endocrinol Metabol. 2009;53(2):281-7.
13. Camargos AF, Melo VH, Carneiro MM, Reis FM. Ginecologia ambulatorial baseada em evidências científicas. 2. ed. Belo Horizonte: Coopmed; 2008. p. 288-90.

14. Harte C, Henry MT, Murphy KD, Mitchell TH. Progestogens and Cushing's syndrome. Ir J Med Sci. 1995;164(4):274-5.

15. Toth MJ,Tchernof A, Sites CK, Poehlman ET. Effect of menopausal status on body composition and abdominal fat distribution. Int $\mathrm{J}$ Obes Relat Metab Disord. 2000;24(2):226-31.

16. Perseghin G, Ghosh S, Gerow K, Shulman GI. Metabolic defects in lean nondiabetic offspring of NIDDM parents: a cross-sectional study. Diabetes. 1997;46(6):1001-9.

17. Boden G. Obesity and free fatty acids. Endocrinol Metab Clin North Am. 2008;37(3):635-46, viii-ix.

18. Hauner $\mathrm{H}$. Secretory factors from human adipose tissue and their functional role. Proc Nutr Soc. 2005;64(2):163-9.

19. Halberg N, Wernstedt-Asterholm I, Scherer PE. The adipocyte as an endocrine cell. Endocrinol Metab Clin North Am. 2008;37(3):75368, x-xi.

20. Pratley RE, Nicolson M, Bogardus C, Ravussin E. Plasma leptin responses to fasting in Pima Indians. Am J Physiol. 1997;273/3 Pt 1):E644-9.

21. Considine RV, Sinha $M K$, Heiman ML, Kriauciunas $A$, Stephens TW, Nyce MR, et al. Serum immunoreactive-leptin concentrations in normal-weight and obese humans. $\mathrm{N}$ Engl J Med. 1996;334(5):292-5.

22. Weigle DS, Duell PB, Connor WE, Steiner RA, Soules MR, Kuijper $\mathrm{JL}$. Effect of fasting, refeeding, and dietary fat restriction on plasma leptin levels. J Clin Endocrinol Metab. 1997;82(2):561-5.

23. Rajala MW, Scherer PE. Minireview: The adipocyte--at the crossroads of energy homeostasis, inflammation, and atherosclerosis. Endocrinology. 2003;144(9):3765-73.

24. Wang Z, Nakayama T. Inflammation, a link between obesity and cardiovascular disease. Mediators Inflamm. 2010;2010:535918.

25. Pelkman CL, Chow M, Heinbach RA, Rolls BJ. Short-term effects of a progestational contraceptive drug on food intake, resting energy expenditure, and body weight in young women. Am J Clin Nutr. 2001;73(1):19-26.

26. Steward RG, Bateman LA, Slentz C, Stanczyk FZ, Price TM. The impact of short-term depot-medroxyprogesterone acetate treatment on resting metabolic rate. Contraception. 2016;93(4):317-22.

27. Johnstone AM, Murison SD, Duncan JS, Rance KA, Speakman $J R$. Factors influencing variation in basal metabolic rate include fat-free mass, fat mass, age, and circulating thyroxine but not sex, circulating leptin, or triiodothyronine. Am J Clin Nutr. 2005;82(5):941-8. 